\title{
Factors Associated With Adherence To
}

\section{Anti-Retroviral Therapy Among People Living With HIVIAIDS At Wangaya Hospital In Denpasar, Bali, Indonesia: A Cross-Sectional Study}

This article was published in the following Dove Press journal:

HIVIAIDS - Research and Palliative Care

\author{
Ketut Suryana (D) \\ Hamong Suharsono ${ }^{2}$ \\ I Gede Putu Jarwa Antara ${ }^{3}$ \\ 'Department of Internal Medicine, \\ Wangaya Hospital in Denpasar, Denpasar, \\ Bali, Indonesia; ${ }^{2}$ Department of \\ Biochemistry, Veterinary Faculty of \\ Udayana University in Denpasar, \\ Denpasar, Bali, Indonesia; ${ }^{3}$ Department \\ of Internal Medicine, Medical Faculty of \\ Udayana University-Sanglah Hospital in \\ Denpasar, Denpasar, Bali, Indonesia
}

Background: Acquired Immunodeficiency Syndrome (AIDS) is a major public health problem. Recently AIDS was considered as a manageable chronic disease. High adherence to Anti-Retroviral Therapy (ART) is necessary to achieve undetectable viral load, reduce morbidity, mortality and to improve the quality of life. It is also preventing the drug resistance, reducing the transmission and finally leading to live longer and healthier.

Objectives: To assess the factor associated with ART adherence among people living with HIV/AIDS (PLWHA) at Wangaya Hospital, in Denpasar, Bali, Indonesia.

Methodology: A cross-sectional study was carried out during January 2015-December 2017 among 202 PLWHA taking ART for at least 6 months. The participants were interviewed using a semi-structured questionnaire to obtain data on socio-demographic characteristics. The data were analyzed using SPSS software for windows version 24.0. Chi-square test was done, the precision value of $95 \%(\mathrm{p}<0.05)$ was considered statistically to be significant.

Results: A total of 202 PLWHA taking ART, 170 (84.16\%) were reported with high adherence ( $\geq 95 \%)$, 32 (15.84\%) were low adherence $(<95 \%)$. Factors found to be independently associated with high adherence to ART were employment status/occupation $(p=0.011)$, type of ARV (due to adverse effect of ART) $(p=0.002)$ and family support $(p<0.001)$.

Conclusion: This study found that the factor associated with ART adherence among PLWHA who visited Wangaya Hospital, in Denpasar, Bali, Indonesia, was employment status, type of ARV and family support.

Keywords: adherence, anti retroviral therapy, people living with HIV/AIDS

\section{Introduction}

The Health Ministry of the Republic of Indonesia reported that the number of HIV cases from 2005 to 2017 increased from the annual number. The cumulative number of HIV infections released until December 2017 was 280,623. The highest number of infections were DKI Jakarta (51,981), East Java (39,633), Papua $(29,083)$, West Java $(28,964)$ and Central Java $(22,292)$. In 2017, there were 48,300 people living with HIV in Indonesia, in Bali 2,441 people were confirmed with HIV infection. The number of AIDS released from 2005 to 2017 was relatively stable every year. The cumulative number of AIDS from 1987 to December 2017 totaled 102,667 people. The highest number of AIDS were from Papua $(19,729)$,
Correspondence: Ketut Suryana Department of Internal Medicine, Wangaya Hospital Denpasar Jalan Akasia VIII No 22 Denpasar, Bali, Indonesia 80235, Bali Indonesia

Tel +6285953783944

Email ketutsuryana@gmail.com 
East Java $(18,243)$, Jakarta City $(9,215)$, Central Java $(8,170)$, Bali $(7,441)$ and West Java $(6,502)$.

The use of combination Anti Retroviral (ARV) initiated in the late 1990s. It was proven effective in suppressing viral replication and had changed the natural course of the disease, had decreased morbidity and mortality. ${ }^{1-6}$ Both Human Immunodeficiency Virus (HIV) infection and Acquired Immunodeficiency Syndrome (AIDS) remained as the major public health problem in the world. ${ }^{3,7}$ Currently, HIV infection is proven to be a disease with chronic inflammation and potentially controllable. Thus, new issues related to the manageable disease have appeared, including the adherence to $\mathrm{ART}^{8}{ }^{8}$ Indeed, adherence to ART is an essential for long-term therapeutic success and is therefore this therapy becomes a major concern. ${ }^{4}$ On the other hand, medical knowledge around HIV/AIDS has increased significantly over the years and a good progress has been made in the treatment of HIV as a manageable life-threatening chronic condition using ART. ${ }^{2-5,9,10}$ The ART program progress beyond knowledge development among PLWHA; a partnership between them and healthcare providers is required, with the HIV-infected person assuming the major responsibility of self-care that will result in adherence and a good clinical outcome. To achieve and to maintain controlled HIV infection, the absence of viral resistance, one of the most important aspects is the client's adherence to the ART program. ${ }^{6-12}$ Improving adherence requires collaboration with the patients in order to understand and to improve the individual impediments to adherence. ${ }^{13,14}$

This study explores the rates and the factors associated with ART adherence among adult PLWHA at Wangaya Hospital, in Denpasar, Bali, Indonesia.

\section{Methodology}

\section{Study Population And Design}

A hospital-based cross-sectional study was conducted among 202 adult PLWHA (aged $\geq 18$ years) taking ART for at least 6 months. Biopsychosocial approach (comprehensive care support treatment) should be provided to all adult PLWHA during the visit generally every 30 days routinely and who were given a written informed consent. The participants were interviewed about the socio-demographic characteristics, the duration of taking ART. The associated factors with ART adherence among PLWHA such as: age, sex, education, employment status/occupation, address (travel burdens), type of ARV and support.

\section{Measurement Of Adherence}

The used method for measuring adherence in this study is by using the pill counts. Pill counts, by counting the number of pills that remain in the patients' bottles. The patients bring back the actual pill containers in order for the clinicians to physically count the leftover pills. Pill counts were assessed retrospectively based on 30 days recall. The adherence index was calculated by the formula:

$$
\frac{\text { Total number of drugs taken (for } 30 \text { days) }}{\text { Total number of drugs prescribed (for } 30 \text { days) }} \times 100
$$

PLWHA with $\geq 95 \%$ of adherence were considered as having high adherence and those with less than $95 \%$ were considered as having low adherence. ${ }^{15-20}$

\section{Statistical Analysis}

The data were collected and analyzed using Statistical Package for Social Sciences (SPSS). Statistics for windows version 24.0. To verify the association among the independent variables such as socio-demographic characteristics and others to ART adherence, crude odds ratio (OR) with $95 \%$ CI was calculated by chi-square test, with $\mathrm{p}$ value of $<0.05$ was considered statistically significant.

\section{Ethical Clearance}

The study procedure was approved by Ethical Committee of Wangaya Hospital in Denpasar, Bali, Indonesia with register number: 02/RSUDW/Litbang/2015. The study was conducted in accordance with the Declaration of Helsinki. We collect the data from the patients who visited Wangaya Hospital, in Denpasar, Bali, Indonesia. Written informed consent was obtained from all the participants.

\section{Results}

\section{Characteristics Of The Study Participant}

This study goal is to assess the factor associated with ART adherence among people living with HIV/AIDS (PLWHA) at Wangaya Hospital, in Denpasar, Bali, Indonesia. The ART adherence was assessed by interviewing and pill counts within the past 30 days prior. Reported with high adherence if as taking $\geq 95 \%$ of their pills during the previous 30 days and low adherence if as taking $<95 \%$ of their pills during the previous 30 days. On this study, 202 participants analyzed, the overall adherence levels 170 (84.16\%) participants were reported with high adherence but $32(15.84 \%)$ participants with low adherence. 
Table I Associated Factors To Adherence Levels Among PLWHA (N=202)

\begin{tabular}{|c|c|c|c|}
\hline Variable & $\begin{array}{l}\text { Low Adherence } \mathbf{N}=32 \text { ( } 15.84 \%) \\
N(\%)\end{array}$ & $\begin{array}{l}\text { High Adherence } N=170 \text { (84. } 16 \%) \\
\text { N (\%) }\end{array}$ & p-value \\
\hline $\begin{array}{l}\text { Age (year) } \\
\quad<35 \\
\quad \geq 35\end{array}$ & $\begin{array}{l}20(62.50 \%) \\
12(37.50 \%)\end{array}$ & $\begin{array}{l}80(47.10 \%) \\
90(52.90 \%)\end{array}$ & $p=0.109$ \\
\hline $\begin{array}{l}\text { Sex } \\
\text { Male } \\
\text { Female }\end{array}$ & $\begin{array}{l}17(53.00 \%) \\
15(47.00 \%)\end{array}$ & $\begin{array}{l}106(62.00 \%) \\
64(38.00 \%)\end{array}$ & $\mathrm{p}=0.326$ \\
\hline $\begin{array}{l}\text { Education } \\
\text { Uneducated } \\
\text { Elementary School } \\
\text { Junior High School } \\
\text { High School } \\
\text { University }\end{array}$ & $\begin{array}{l}\text { I (3.00\%) } \\
5(16.00 \%) \\
6(19.00 \%) \\
\text { I7 (53.00\%) } \\
3(9.00 \%)\end{array}$ & $\begin{array}{l}2(1.00 \%) \\
23(14.00 \%) \\
31(18.00 \%) \\
98(58.00 \%) \\
16(9.00 \%)\end{array}$ & $p=0.928$ \\
\hline $\begin{array}{l}\text { Employment status/occupation } \\
\text { Employed } \\
\text { Unemployed }\end{array}$ & $\begin{array}{l}9(28.00 \%) \\
23(72.00 \%)\end{array}$ & $\begin{array}{l}151(89.00 \%) \\
19(11.00 \%)\end{array}$ & $\mathrm{p}=0.01 \mathrm{I} *$ \\
\hline $\begin{array}{l}\text { Address (travel burdens) } \\
\text { Denpasar } \\
\text { Out of Denpasar }\end{array}$ & $\begin{array}{l}26(81.00 \%) \\
6(19.00 \%)\end{array}$ & $\begin{array}{l}\text { I25 (74.00\%) } \\
45(26.00 \%)\end{array}$ & $P=0.356$ \\
\hline $\begin{array}{l}\text { Type of ARV } \\
\text { (due to adverse effect) } \\
\text { FDC } \\
\text { Non-FDC }\end{array}$ & $\begin{array}{l}24(75.00 \%) \\
8(25.00 \%)\end{array}$ & $\begin{array}{l}77(45.00 \%) \\
93(55.00 \%)\end{array}$ & $p=0.002^{*}$ \\
\hline $\begin{array}{l}\text { Support } \\
\text { No support } \\
\text { Family } \\
\text { NGO }\end{array}$ & $\begin{array}{l}8(25.00 \%) \\
2(6.25 \%) \\
22(68.75 \%)\end{array}$ & $\begin{array}{l}56(33.00 \%) \\
73(43.00 \%) \\
41(24.00 \%)\end{array}$ & $\mathrm{P}<0.00 \mathrm{I}^{*}$ \\
\hline
\end{tabular}

Notes: ${ }^{\#}$ Age in median. *Significant $p<0.005$.

Abbreviations: ARV, Anti Retroviral; FDC, Fixed Dose Combination; NGO, Non-Government Organization.

Data characteristics and associated factors to ART adherence among PLWHA of the study participant are shown in Table 1.

We found that $100(49.50 \%)$ of the study participants were in the age group below 35 years old and $102(50.50 \%)$ the age group above 35 years old. They were male 123 (60.89\%) and 79 (39.11\%) were female. Regarding education status, mostly, 115 (56.93\%) of the participants were graduated from high school followed by junior high school $37(18.32 \%)$, elementary school $28(13.86 \%)$, graduated from university $19(9.40 \%)$ and the uneducated $3(1.49 \%)$. The participants were employed 174 (86.14\%), unemployed $28(13.86 \%)$, they were majority $151(74.75 \%)$ live in Denpasar and $51(25.25 \%)$ live out of Denpasar. Participants taking Fixed Dose Combination (FDC) were equal to participants taking non-FDC. Most 75 (37.13\%) of the participants were supported by their family, followed by no support $64(31.69 \%)$ and $63(31.18 \%)$ supported by Non-Government Organization (NGO).

In this study, we found statistically significant association between ART adherence with employment status/ occupation ( $\mathrm{p}=0.011$ ), type of ARV (due to adverse effect) $(p=0.002)$, family support $(p<0.001)$. There was no association between ART adherence with age $(p=0.099)$, sex $(p=0.326)$, education $(p=0.928)$ and address (travel burdens) $(\mathrm{p}=0.356)$.

Mostly the participants took their ARV drugs showed the high adherence but 32 (15.84\%) of them were with low adherence. The reasons for missing the adherence were feeling healthy: 12 (5.94\%), adverse effects of ARV: 9 (4.46\%), busy: 5 (2.48\%), and far from home: 3 (1.48\%) (Figure 1). 


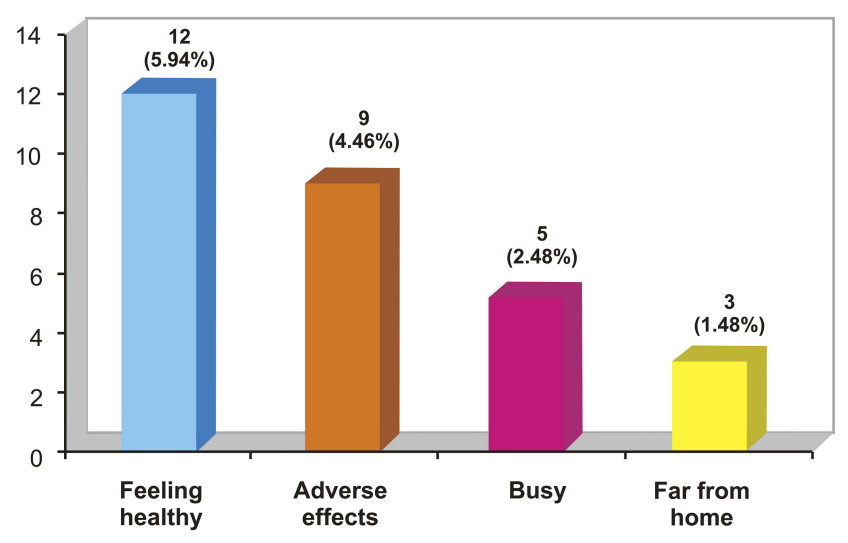

Figure I The reason for missing the adherence to ART.

\section{Discussion}

Adherence is a major issue in management of chronic disease, such as in management of HIV patients. ${ }^{14,21}$ In HIV, studies indicate that high levels of ART adherence are necessary for viral suppression, prevention of ART resistance, disease progression and reduce the transmission risk. ${ }^{9,14}$ ART adherence is influenced by a number of factors, including regimen complexity and drug toxicity. ${ }^{15,22,23}$

A total of 202 participants in this study, $84.16 \%$ (170 participants) were high adherence but 32 (15.84\%) participants reported low adherence. We found statistically significant association between ART adherence with employment status/occupation, type of ARV (due to adverse effect), family support but no association with age, sex, education and address (travel burdens).

The statistically significant association between employment status/occupation and ART adherence $(\mathrm{p}=0.011)$. Another study: Prah et al (2018) reported that occupation/ employment status was significantly associated with adherence to ART ( $<<0.0031) .{ }^{14}$ Safira et al (2016) reported that occupation/employment status was significantly associated with adherence to ART $(\mathrm{p}=0.003) .{ }^{15}$ Suleiman et al (2016) found that occupation/employment status was significantly associated with adherence to ART $(\mathrm{p}=0.0008) .{ }^{16}$ Ibrahim et al (2014) found that those who were unemployed are more likely to be associated with poor adherence to ART $(\mathrm{p}=0.011) .{ }^{17} \mathrm{~A}$ study conducted by Talam et al (2008) showed that employment status associated with adherence to ART $(\mathrm{p}=0.000) .{ }^{18}$

Furthermore, other aspects contribute to the effectiveness of ART, such as the capacity of the patients in adhering to special instructions regarding dose intervals due to ARV taking routinely. ${ }^{2}$

This study found that type of ARV (due to adverse effect of ARV) was statistically significantly associated with ART adherence $(\mathrm{p}=0.002)$. Another study: Cheng et al (2018) reported that type of ARV (side effect of treatment) associated with adherence to ART ( $\mathrm{p}<$ 0.001). ${ }^{24}$ Achappa et al (2013) reported that side effect of treatment associated with adherence to ART ( $\mathrm{p}=$ $0.001){ }^{25}$ Oliveira et al (2018) found that adverse effects of the drugs associated with adherence to ART ( $\mathrm{p}=$ 0.0009). ${ }^{1}$ A study conducted by Shigdel et al (2014) showed that adverse effects of treatment associated with adherence to ART $(p=0.005){ }^{26}$

Family support boosts the patients self-esteem and it becomes easy for the patient to adhere to ART and to believe that the patients will have a long and healthy life. In contrast, if a patient does not have the support from their family, it becomes difficult for the patient because the situation brings them to be hopeless, to be potential to refuse the treatment and to be low adherence. ${ }^{9}$ This study has shown that family support was statistically significantly associated with ART adherence $(\mathrm{p}<0.001)$. Achappa et al (2013) found that a good family care/support statistically significant associated with ART adherence $(p=0.0001)$. A meta-analysis reported that adherence is 1.74 times higher in participants from cohesive families. ${ }^{25}$ Yathiraj et al (2016) reported that the participants with a good family care $(74.0 \%$; $\mathrm{OR}=3.0, \mathrm{CI}=1.2,5.2)$ were found to be adherent to ART $(\mathrm{p}<0.05) .{ }^{27}$ Joseph et al (2018) found that partners/family support statistically significant associated with ART adherence $(\mathrm{p}<0.001){ }^{28}$

Koyra HC (2018) reported that the major reasons for not adhering to ART in PLWHA at Dubbo St. Marry Hospital, Southern Ethiopia were forgetting to take medications $48(36.00 \%)$ followed by fear of adverse effects 32 (24.00\%), hopelessness $23(17.00 \%)$, being busy 17 $(13.00 \%)$, distance from home $11(8.00 \%)$ and others 3 $(2.20 \%){ }^{29}$ This study found that the major reasons for not adhering to ART were feeling healthy: 12 (5.94\%), adverse effects of ARV: 9 (4.46\%), busy: 5 (2.48\%), and far from home: $3(1.48 \%)$.

This study found that there is no association between adherence to ART and age, sex, education, address (travel burdens). Other studies found no association between adherence to ART and age, sex, education. ${ }^{30-40}$ Byabene et al (2017) reported that adherence to ART was not associated with time to clinic (travel burdens) $(p=0.07){ }^{41}$

\section{Conclusion}

Mostly the participants are in high adherence. A statistically significant association was observed between ART adherence 
with employment status/occupation, type of ARV (due to adverse effect) and family support. The reasons for missing the adherence were mostly due to feeling healthy and followed by adverse effects, busy, and far from home.

\section{Limitations Of Study}

The limitations of this study included its small sample size. This study was conducted at Wangaya Hospital in Denpasar, Bali-Indonesia during January 2015-December 2017. Since this is a hospital-based study which only included PLWHA who attended the Wangaya Hospital in Denpasar, Bali-Indonesia during the study period, so the result cannot be generalized to all PLWHA in Indonesia. The Secondary data were reviewed to identify the clinical markers in addition to primary data. Patient self-report was used and it was subject to recall bias and overestimate adherence level. The use of a cross-sectional design limited the degree to which causal inferences and generalizations could be made from the research findings.

\section{Acknowledgments}

We would like to thank the Director of Wangaya Hospital, all of the participants and their family, the Wangaya HIV Study Group staff, all of our colleagues who supported this study and Puji Astuti who was contributed to the data collection.

\section{Author Contributions}

All authors made substantial contributions to conception and design, acquisition of data, or analysis and interpretation of data; took part in drafting the article or revising it critically for important intellectual content; gave final approval of the version to be published; and agree to be accountable for all aspects of the work.

\section{Disclosure}

The authors report no conflicts of interest in this work.

\section{References}

1. Oliveira LS, Caixeta LM, Martins JLR, et al. Adherence to antiretroviral therapy and correlation with adverse effects and coinfections in people living with HIV/AIDS in the municipality of Goiás State. Rev Soc Bras Med Trop. 2018;51(4):436-444. doi:10.1590/0037-86820467-2017

2. Silva MCF, Ximenes RAA, Miranda FDB, et al. Risk-factors for nonadherence to antiretroviral therapy. Rev Inst Med Trop S Paulo. 2009;51(3):135-139. doi:10.1590/S0036-46652009000300003

3. Hornschuh S, Dietrich JJ, Tshabalal C, Laher F. Antiretroviral treatment adherence knowledge and experience among adolescents and young adults in Soweto South Africa. AIDS Res Treat. 2017;2017:18. doi: $10.1155 / 2017 / 5192516$
4. Azia IN, Mukumbang FC, Van Wyk B. Barriers to adherence to antiretroviral treatment in a regional hospital in Vredenburg, Western Cape, South Africa. S Afr J HIV Med. 2016;17(1):a476. doi:10.4102/sajhivmed.v17i1.476

5. Fonsah JY, Nijamnshi AK, Kouanfack C, et al. Adherence to antiretroviral therapy (ART) in Yaounde Cameroon: association with opportunistic infections, depression, ART regimen and side effects. PLoS One. 2017;12(1):1-19. doi:10.1371/journal.pone.0170893

6. Miyada S, Garbin AJI, Gatto RCJ, Garbin CAS. Treatment adherence in patients living with HIV/AIDS assisted at a specialized facility in Brazil. Rev Soc Bras Med Trop. 2017;50(5):607-612. doi:10.1590/ 0037-8682-0266-2017

7. Kahema SE, Mgabo MR, Emidi B, Sigalla GN, Kajeguka DC. Factors influencing adherence to antiretroviral therapy among HIV infected patients in Nyamagana-Mwanza, Northern Tanzania: a cross sectional study. Int Arch Med Microbiol. 2018;1:002.

8. Hirsch JD, Gonzales M, Rosenquist A, Miller TA, Gilmer TP, Best BM. Antiretroviral therapy adherence, medication use, and health care costs during 3 years of a community pharmacy medication therapy management program for medical beneficiaries with HIV/ AIDS. J Manag Care Pharm. 2011;17(3):213-223. doi:10.18553/ jmcp.2011.17.3.213

9. Adefolalu A, Nkosi Z, Olorunju S, Masemola P. Self-efficacy, medication beliefs and adherence to antiretroviral therapy by patients attending a health facility in Pretoria. S Afr Fam Pract. 2014;56 (5): $1-5$.

10. Bam K, Rajbhandari RM, Karmacharya DB, Dixit SM. Strengthening adherence to antiretroviral therapy (ART) monitoring and support: operation research to identify barriers and facilitators in Nepal. BMC Health Serv Res. 2015;15:188. doi:10.1186/s12913-015-0846-8

11. Zegeye S, Sendo EG. Adherence to antiretroviral therapy among HIV-infected children attending hiwot fana and dil-chora art clinic at referral hospitals in Eastern Ethiophia. J HIV Clin Scientific Res. 2015;2(1):8-14.

12. Lencha B, Hasen K, Getachew T, Abdi M, Habtamu M. Adherence to antiretroviral therapy and associated factors among people living with HIV/AIDS at Gobba hospital, Southeast Ethiophia: an institutional based study. Qua Prim Care. 2015;23(6):336-341.

13. Yaya I, Landoh DE, Saka B, et al. Predictors of adherence to antiretroviral therapy among people living with HIV and AIDS at the regional hospital of Sokodé, Togo. BMV Public Health. 2014;14:1308. doi:10.1186/1471-2458-14-1308

14. Prah J, Hayfron-Benjamin A, Abdulao M, Lasim O, Nartey Y, ObiriYeboah D. Factors affecting adherence to antiretroviral therapy among HIV/AIDS patients in Cape Coast Metropolis, Ghana. J HIV AIDS. 2018;4:1-7.

15. Safira N, Lubis R, Fahdhy M. Factors affecting adherence to antiretroviral therapy. The 2nd international meeting of public health 2016 with theme public health perspective of sustainable development goals: the challenge and opportunities in Asia-Pacific region. $K n E$ Life Sci. 2018;60-70.

16. Suleiman IA, Momo A. Adherence to antiretroviral therapy and its determinants among persons living with HIV/AIDS in Bayelsa state, Nigeria. Pharm Prac. 2016;14(1):631.

17. Ibrahim Y, Sutan R, Latif KBA, Al-Abed AA, Amara A, Adam I. Poor adherence to antiretroviral therapy and associated factors among people living with HIV in Omdurman City, Sudan. Malaysian $J$ Public Health Med. 2014;14(1):90-101.

18. Talam NC, Gatongi P, Rotich J, Kimaiyo S. Factors affecting antiretroviral drug adherence among HIV/AIDS adult patients attending HIV/AIDS clinic at Moi teaching and referral hospital, Eldoret Kenya. East Afr J Public Health. 2008;5(2):74-78.

19. Muiyuro M, Ngure K, Mutai J, Ng'ang'a M. Adherence to highly active antiretroviral therapy and associated factors among HIV positive adolescents in Kenya. IOSR J Humanities Social Sci. 2019;24 (1):17-25. 
20. Beng CA, Sanchez L, Campos JR, Perez J. Antiretroviral therapy adherence in persons with HIV/AIDS in Cuba. MEDICC Rev. 2011;13(2):17-23

21. Adefolalu AO, Nkosi ZZ. The complex nature of adherence in the management of HIV/AIDS as a chronic medical condition. Disease. 2013;1:18-35. doi:10.3390/diseases 1010018

22. Letta S, Demissie A, Oljira L, Dessie Y. Factors associated with adherence to antiretroviral therapy (ART) among adult people living with HIV and attending their clinical care, Eastern Ethiophia. BMC Int Health Hum Rights. 2015;15:1-7. doi:10.1186/s12914-015-0071-x

23. O'Connor JL, Gardner EM, Mannheimer SB, et al. Factors associated with adherence amongst 5295 people receiving antiretroviral therapy as part of an international trial. J Infect Dis. 2013;208:40-49. doi:10.1093/infdis/jis 731

24. Cheng Y, Nickman NA, Jamjian C, et al. Predicting poor adherence to antiretroviral therapy among treatment-naïve veterans infected with human immunodeficiency virus. Medicine. 2018;97:1-7.

25. Achappa B, Madi D, Bhaskaran U, Ramapuram JT, Rao S, Mahalingam S. Adherence to antiretroviral therapy among people living with HIV. N Am J Med Sci. 2013;5:220-223. doi:10.4103/ 1947-2714.109196

26. Shigdel R, Klouman E, Bhandari A, Ahmed LA. Factors associated with adherence to antiretroviral therapy in HIV-infected patients in Kathmandu District, Nepal. Hiv Aids. 2014;6:109-116.

27. Yathiraj AB, Unnikrishnan B, Ramapuram JT, et al. Factors influencing adherence to antiretroviral therapy among people living with HIV in Coastal South India. J Int Assoc Provid AIDS Care. 2016;15 (6):529-533. doi:10.1177/2325957416661424

28. Joseph A, Ogah OE, Robinson O, Matthew NI, Ukaegbechukwuemeka IA. Determinants of adherence to antiretroviral therapy among HIV-positive women accessing prevention of mother to child transmission services in Ebonyi State, Nigeria. Ann Med Health Sci Res. 2018;8:248-253.

29. Koyra HC. Adherence to antiretroviral therapy among adult persons living with HIV/AIDS in Southern Ethiopia. Int J Virol AIDS. 2018;5:038.

30. Roux P, Kounfack C, Cohen J, et al. Adherence to antiretroviral treatment in HIV-positive patients in the Cameroon context: promoting the use of medication reminder methods. J Acquir Immune Defic Syndr. 2011;57(6S):S40-S43. doi:10.1097/QAI.0b013e318222b5c2

31. Kim J, Lee E, Park BJ, Bang JH, Lee JY. Adherence to antiretroviral therapy and factors affecting low medication adherence among incident HIV-infected individuals during 2009-2016: a nationwide study. Sci Rep. 2018;8:3133. doi:10.1038/s41598-018-21081.
32. Kasumu LO, Balogun MR. Knowledge and attitude towards antiretroviral therapy and adherence pattern of HIV patients in southwest Nigeria. Int $J$ Infect Control. 2014;v10:i3. doi:10.3396/IJIC. v10i3.024.14

33. Kheswa JG. Non-adherence to antiretroviral treatment by people living with HIV/AIDS in black communities in South Africa: sociocultural challenges. Mediterr J Soc Sci. 2014;5(14):450-457.

34. Nduaguba SO, Soremekun RO, Olugbake OA, Barner JC. The relationship between patient-related factors and medication adherence among Nigerian patients taking highly active anti-retroviral therapy. Afr Health Sci. 2017;17(3):738-745. doi:10.4314/ahs.v17i3.16

35. Mohammed AY, Ahmed MB, Tefera TB. Assessment of factors art adherence among people living with human immune virus in Bale Robe Hospital, South East Ethiopia. Am J Public Health Res. 2015;3:60-67.

36. Lemos LDA, Fluza MLT, Reis RK, Ferrer AC, Gir E, Galvao MTG. Adherence to antiretrovirals in people coinfected with the human immunodeficiency virus and tuberculosis. Rev Latino-Am Enfermagem. 2016;24:e2691. doi:10.1590/1518-8345.0537.2691

37. Poudel K, Buchanan D, Amiya R, Poudel-Tandukar K. Perceived family support and antiretroviral adherence in HIV-positive individuals: results from a community-based positive living with HIV study. Int Q Community Health Educ. 2015;201:1-19.

38. Mai HT, Le MG, Tran BX, et al. Adherence to antiretroviral therapy among HIV/AIDS patients in the context of early treatment initiation in Vietnam. Patients Preference Adherence. 2018;12:2131-2137. doi:10.2147/PPA.S175474

39. Mukui IN, Ng'ang'a L, Wiliamson J, et al. Rates and predictors of non-adherence to antiretroviral therapy among HIV-positive individuals in Kenya: results from the second Kenya AIDS indicator Survey, 2012. PLoS ONE. 2016;11(12):e0167465. doi:10.1371/journal.pone. 0167465

40. Ohl M, Perencevich E, Mclnnes K, et al. Antiretroviral adherence among rural compared to urban veterans with HIV infection in the United States. AIDS Behav. 2013;17:174-80.

41. Byabene AK, Deguenonvo LF, Niang K, Manga MN, Bulabula ANH. Optimal antiretroviral therapy adherence as evaluated by CASE index score tool is associated with virological suppression in HIV-infected adults in Dakar, Senegal. Trop Med Int Health. 2017;22(6):776-782. doi:10.1111/tmi.12882
HIV/AIDS - Research and Palliative Care

\section{Publish your work in this journal}

HIV/AIDS - Research and Palliative Care is an international, peerreviewed open-access journal focusing on advances in research in HIV, its clinical progression and management options including antiviral treatment, palliative care and public healthcare policies to control viral spread. The manuscript management system is completely online and includes a very quick and fair peer-review system, which is all easy to use. Visit http://www.dovepress.com/testimonials.php to read real quotes from published authors. 